\title{
DETECTION OF VIRULENCE GENES IN ENVIRONMENTAL STRAINS OF Vibrio cholerae FROM ESTUARIES IN NORTHEASTERN BRAZIL
}

Francisca Gleire Rodrigues de MENEZES(1), Soraya da Silva NEVES(1), Oscarina Viana de SOUSA(2), Candida Machado Vieira Maia VILA-NOVA(2), Rodrigo MAGgIONI(2), Grace Nazareth Diogo THEOPHILO(3), Ernesto HOFER(3) \& Regine Helena Silva dos Fernandes VIEIRA(2)

\begin{abstract}
SUMMARY
The objectives of this study were to detect the presence of Vibrio cholerae in tropical estuaries (Northeastern Brazil) and to search for virulence factors in the environmental isolates. Water and sediment samples were inoculated onto a vibrio-selective medium (TCBS), and colonies with morphological resemblance to $V$. cholerae were isolated. The cultures were identified phenotypically using a dichotomous key based on biochemical characteristics. The total DNA extracted was amplified by PCR to detect omp $W$ and by multiplex PCR to detect the virulence genes $c t x$, $t c p$, zot and $r f b O 1$. The results of the phenotypic and genotypic identification were compared. Nine strains of $V$. cholerae were identified phenotypically, five of which were confirmed by detection of the speciesspecific gene omp $W$. The dichotomous key was efficient at differentiating environmental strains of $V$. cholerae. Strains of $V$. cholerae were found in all four estuaries, but none possessed virulence genes.
\end{abstract}

KEYWORDS: Cholera; Estuaries; Pathogenicity; Genes.

\section{INTRODUCTION}

The genus Vibrio (family: Vibrionaceae) comprises 104 species $^{6}$, some of which are pathogenic to humans. One of the best known of these is the Gram-negative species Vibrio cholerae, which is capable of inducing cholera, an acute intestinal infection, when ingested through contaminated water and food ${ }^{16}$.

In the early 1960s, Colwell demonstrated the importance of aquatic environments to the ecology and epidemiology of $V$. cholera $^{35}$, contrary to the earlier notion that the organism could only be transmitted by a human source and that water served merely to carry it from host to host.

V. cholerae is widely distributed in estuarine, marine and freshwater environments and has been associated with outbreaks of endemic, epidemic and pandemic proportions $\mathrm{s}^{11,12,23}$.

Over 200 serogroups of $V$. cholerae are known, but only O1 and $\mathrm{O} 139$ have been implicated in epidemic cholera ${ }^{12,36}$, although local sporadic outbreaks of diarrhea associated with non-O1 and non-O139 strains have been documented. Nevertheless, despite the extensive research done over the past years on the ecology, pathogenicity and epidemiological behavior of the species, many questions remain unanswered ${ }^{9,32}$.

In Brazil, cholera reemerged in 1991, after a century of absence.
Between 1992 and 2005, the highest incidences of $V$. cholerae in samples of water from aquatic ecosystems and foods were registered in the northeastern region ${ }^{4}$, especially in the state of Pernambuco, making that state one of the most strongly impacted by cholera ${ }^{8}$. In the state of Ceará, outbreaks were reported between December 1991 and September $1993^{15}$.

The pathogenesis of cholera is complex and involves the synergy of a number of genes, such as $c t x, t c p$, zot and $r f b O 1^{10,12}$. The presence of these genes may be used as an indicator of virulence, although the cholera toxin is considered the most important epidemic marker.

The purpose of the present study was to isolate and test environmental strains of Vibrio cholerae from estuaries in northeastern Brazil, due to the presence of virulence markers.

\section{MATERIAL AND METHODS}

Sampling locations: Sixty-four samples of water $(n=32)$ and sediments $(n=32)$ were collected in the estuaries of the rivers Pacoti, Choró, Pirangi and Jaguaribe (east of Fortaleza, Ceará, northeastern Brazil). Sample collections took place on a monthly basis, between January and April 2009. Two points in each river were chosen: one close to and other far away from the river mouth. The coordinates of the sampling locations were registered by GPS (Garmin III Plus) (Fig. 1): Pacoti $103^{\circ} 49^{\prime} 16.6^{\prime \prime S}$ and $038^{\circ} 24^{\prime} 11.7^{\prime \prime W}$, Pacoti $23^{\circ} 48^{\prime} 52.4^{\prime \prime S}$ and

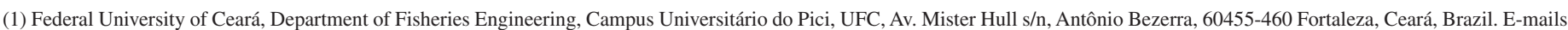
gleirerodrigues@yahoo.com.br (F.G.R.M), sorayasnsol@gmail.com (S.S.NEVES).

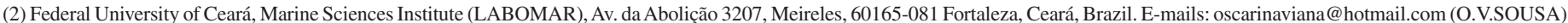
candida.nova@ufc.br (C.M.V.M.VILA-NOVA), rodrigo.maggioni@gmail.com (R.MAGGIONI), regine@labomar.ufc.br (R.H.S.F.VIEIRA)

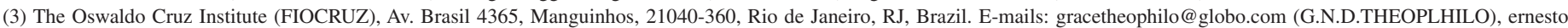
hofer@yahoo.com.br (E. HOFER).

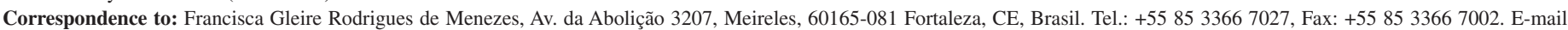
gleirerodrigues@yahoo.com.br 
MENEZES, F.G.R.; NEVES, S.S.; SOUSA, O.V.; VILA-NOVA, C.M.V.M.; MAGGIONI, R.; THEOPHILO, G.N.D.; HOFER, E. \& VIEIRA, R.H.S.F. - Detection of virulence genes in environmental strains of Vibrio cholerae from estuaries in Northeastern Brazil. Rev. Inst. Med. Trop. Sao Paulo, 56(5): 427-32, 2014.

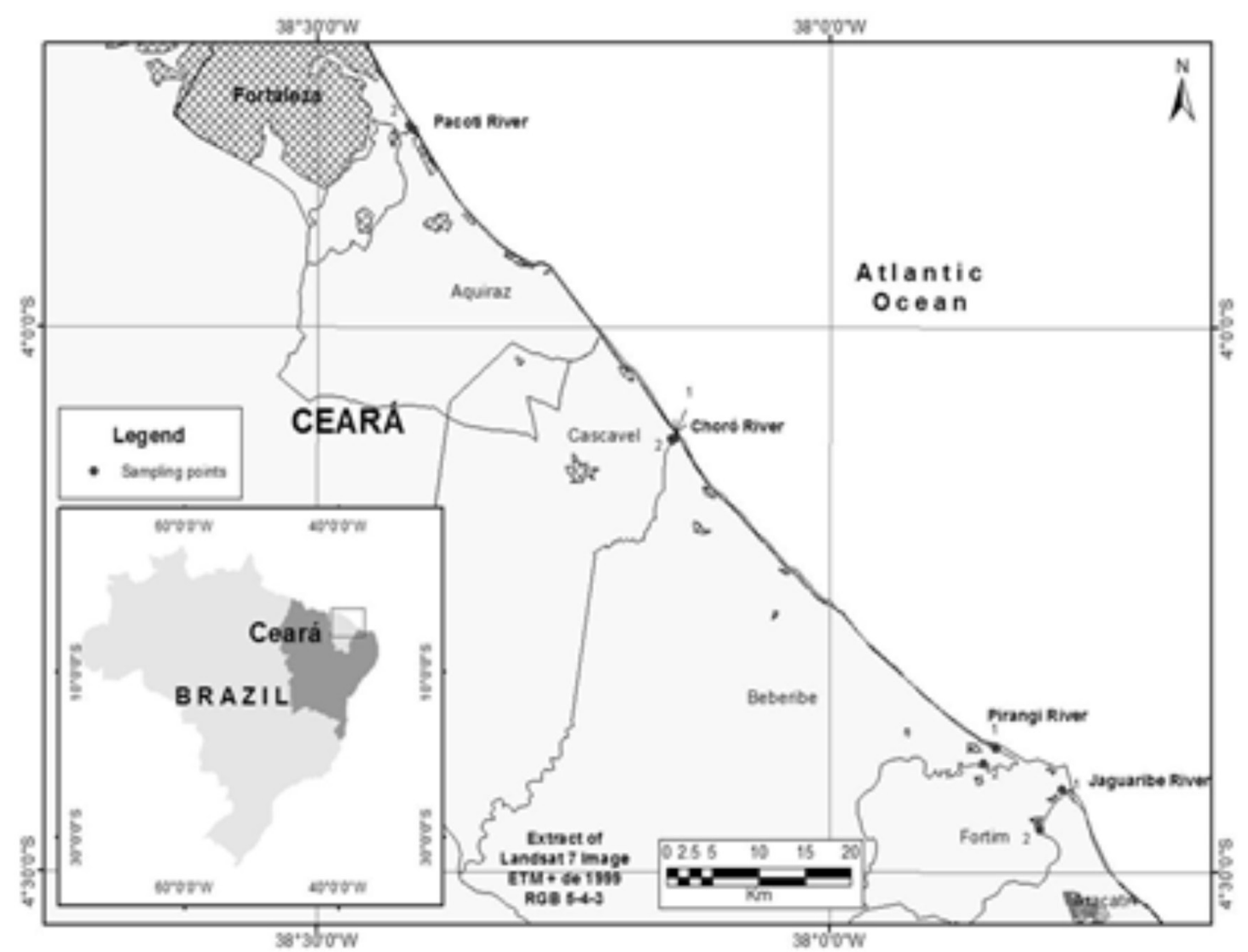

Fig. 1 - Map of the four estuaries Pacoti, Choró, Pirangi and Jaguaribe (Ceará, Brazil) from where water and sediment were sampled between January and April 2009.

038 24'38.1"W, Choró $10^{\circ} 04^{\circ} 06^{\prime} 07.2^{\prime \prime S}$ and $038^{\circ} 09^{\prime} 01.8^{\prime \prime W}$, Choró $204^{\circ} 06^{\prime} 13.2^{\prime \prime S}$ and $038^{\circ} 09^{\prime} 13.8^{\prime \prime} \mathrm{W}$, Pirangi $104^{\circ} 23^{\prime} 11.6^{\prime \prime} \mathrm{S}$ and $037^{\circ} 50^{\prime} 18.4^{\prime \prime} \mathrm{W}$, Pirangi $204^{\circ} 24^{\prime} 03.8^{\prime \prime S}$ and $037^{\circ} 51^{\prime} 00.3^{\prime \prime} \mathrm{W}$, Jaguaribe $104^{\circ} 25^{\prime} 28.7^{\prime \prime S}$ and $037^{\circ} 46^{\prime} 22.5^{\prime \prime} \mathrm{W}$, Jaguaribe $204^{\circ} 27^{\prime} 39.9^{\prime \prime} \mathrm{S}$ and $037^{\circ} 47^{\prime} 39.5^{\prime \prime} \mathrm{W}$.

Collection of samples: Water samples were collected from a depth of $50 \mathrm{~cm}$ and stored in 1-L sterilized amber vials. Core-surface sediment samples were collected using a soil sampler. The samples were transported in isothermal boxes to the Laboratory of Seafood and Environmental Microbiology (LABOMAR/UFC) for immediate analysis. The temperature of the water was registered (thermometer, Incoterm) at the time of sampling.

\section{Isolation of Vibrio cholerae from environmental samples}

Water and sediment samples: The sampled water was used to make serial decimal dilutions (from $10^{-1}$ to $10^{-4}$ ) in alkaline peptone water (APW) at $\mathrm{pH}$ 7.5-8.5. In order to prepare the sediment for analysis, 25-g aliquots were homogenized in $225 \mathrm{~mL}$ APW for 30 minutes $\left(10^{-1}\right)$. Based on this first dilution, subsequent serial decimal dilutions (from $10^{-2}$ to $10^{-4}$ ) were prepared using the same diluent.

One hundred microliters of each dilution was inoculated onto Thiosulfate Citrate Bile salts sucrose (TCBS) agar plates. Inoculated plates were incubated for 18 hours at $37^{\circ} \mathrm{C}$. Colonies with morphological resemblance to $V$. cholerae (2-3 mm diameter, smooth, yellow, slightly flattened with opaque centers and translucent borders) were reseeded in tryptic soy agar (TSA) for purification ${ }^{19}$.

Identification of strains of Vibrio cholerae and detection of pathogenic potential

Phenotypic identification: Following purification, the cultures were submitted to biochemical identification using the dichotomous key of NOGUEROLA \& BLANCH ${ }^{24}$. The standard strains $V$. cholerae O1 Classic 569B and V. cholerae non-O1 IOC 15.177 (supplied by the microbe bank of the Oswaldo Cruz Institute, Rio de Janeiro, Brazil) were used as positive controls. Commercially available antibiotic disks were used to test the susceptibility patterns. Antimicrobial classes used in panel screens included: gentamicin, streptomycin, sulfazotrim, tetracycline, ciprofloxacin, nalidixic acid, penicillin, ampicillin, ceftriaxone, ceftriaxone, aztreonam, cephalothin, chloramphenicol, florfenicol and oxytetracycline. This assay was carried out according to the $\mathrm{CLSI}^{3}$ guidelines.

\section{Genotypic identification}

Extraction of chromosomal DNA: Strains of $V$. cholerae were inoculated in APW $+1 \%$ sodium chloride and incubated at $35^{\circ} \mathrm{C}$ for 24 hours. Subsequently, $1.0-\mathrm{mL}$ aliquots were submitted to DNA extraction using a commercially available kit (DNeasy Blood \& Tissue Kit, Qiagen) ${ }^{12}$. 


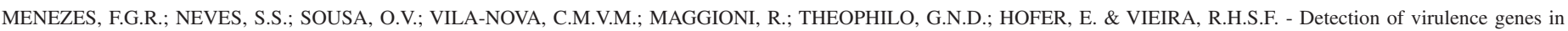
environmental strains of Vibrio cholerae from estuaries in Northeastern Brazil. Rev. Inst. Med. Trop. Sao Paulo, 56(5): 427-32, 2014.

Table 1

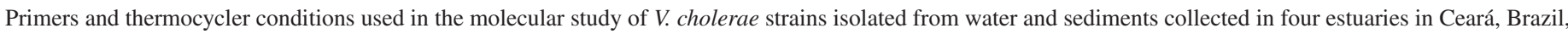
between January and April 2009

\begin{tabular}{|c|c|c|c|c|c|}
\hline Technique & Genes & Primer sequence (5'- 3') & $\begin{array}{c}\text { Thermocycling } \\
\text { conditions }\end{array}$ & $\begin{array}{l}\text { Amplicons } \\
(\text { bp })^{\mathrm{f}}\end{array}$ & Source \\
\hline PCR & $o m p W^{\text {a }}$ & $\begin{array}{l}\text { F: 5' - cac caa gaa ggt gac ttt att gtg- } 3^{\prime} \\
\text { R:5' - ggt ttg tcg aat tag ctt cac c - } 3 \text { ', }\end{array}$ & \multirow{5}{*}{$\begin{array}{c}94^{\circ} \mathrm{C} / 10 \mathrm{~min} . \\
30 \mathrm{cycles} \\
\left(94^{\circ} \mathrm{C} / 1 \mathrm{~min} ., 59^{\circ} \mathrm{C} /\right. \\
\left.1 \mathrm{~min} ., 72^{\circ} \mathrm{C} / 2 \mathrm{~min} .\right) \\
72^{\circ} \mathrm{C} / 10 \mathrm{~min} .\end{array}$} & 304 & \multirow{5}{*}{$\begin{array}{l}\text { GOEL et al., } \\
\text { (2007) }\end{array}$} \\
\hline \multirow{4}{*}{ Multiplex PCR } & $\operatorname{ct} x A B^{\mathrm{b}}$ & $\begin{array}{l}\text { F:5' - gcc ggg ttg tgg gaa tgc tcc aag - } 3^{\prime} \\
\text { R:5 }- \text { gcc ata cta att gcg gca atc gca tg - } 3\end{array}$ & & 536 & \\
\hline & $t c p^{\mathrm{c}}$ & $\begin{array}{l}\text { F:5' - cgt tgg cgg tca gtc ttg- } 3^{\prime} \\
\text { R:5' - cgg get ttc ttc ttg ttc g- } 3\end{array}$ & & 805 & \\
\hline & $r f b O 1^{\mathrm{d}}$ & $\begin{array}{l}F: 5^{\prime}-\text { tct atg } \operatorname{tgc} \operatorname{tgc} \text { gat tgg tg }-3^{\prime} \\
\text { R:5' - ccc cga aaa cct aat gtg ag - } 3^{\prime}\end{array}$ & & 638 & \\
\hline & $z o t^{\mathrm{e}}$ & $\begin{array}{l}\text { F:5' - tcg ctt aac gat ggc gcg ttt t - 3', } \\
\text { R:5'- aac ccc gtt tca ctt cta ccc a - 3' }\end{array}$ & & 947 & \\
\hline
\end{tabular}

omp $W^{\mathrm{a}}=V$. cholerae -specific gene; $c t x A B^{\mathrm{b}}=$ cholera toxin; $t c p^{\mathrm{c}}=$ toxin coregulated pilus; $r f b O 1^{\mathrm{d}}=$ serogroup $\mathrm{O} 1$ identification gene; $z$ ot ${ }^{\mathrm{e}}=$ zonula occludens toxin; $(\mathrm{bp})^{\mathrm{f}}=$ base pair.

Target genes: The identification of $V$. cholerae was confirmed with the primer for the gene $о m p W$, while virulence was evaluated with the primers for the genes $c t x A B$ (cholera toxin), tcp (toxin co-regulated pilus), $r f b O 1$ (serogroup O1) and zot (zonula occludens toxin) ${ }^{12}$. The primers were supplied by Croma BioTechnologies (Brazil) (Table 1). The standard strains V. cholerae O1 Classic 569B and V. cholerae non-O1 IOC 15.177 (supplied by the microbe bank of the Oswaldo Cruz Institute, Rio de Janeiro, Brazil) were used as positive controls.

PCR: Control strains were used in all amplifications. The total DNA extracted was amplified by PCR to detect $\operatorname{omp} W$ (V. cholerae-specific gene) and by multiplex PCR to detect the virulence genes $\operatorname{ctx} A B$ (cholera toxin), $t c p$ (toxin co-regulated pilus), $r f b O 1$ (serogroup $\mathrm{O} 1$ identification gene) and zot (zonula occludens toxin) using a thermocycler (Techne) (Table 2).
Visualization of extraction products and amplicons: The DNA extraction products and amplicons were submitted to electrophoresis in 1\% agarose gel and Gel Red (GelRed Nucleic Acid Gel stain) and viewed under UV light with a Spectroline transilluminator. The runs lasted 60 minutes each and were performed with $7 \times 14 \mathrm{~cm}$ agarose gel at $120 \mathrm{~V}$ and $500 \mathrm{~mA}$. The gels were photo-documented with a digital camera (Kodak EDAS290). A 1000-bp DNA ladder (Sigma) was used as molecular size standard.

\section{RESULTS AND DISCUSSION}

Overall, 212 strains of Vibrio spp. were isolated, 98 of which from water samples and 114 from sediment samples. Nine strains were phenotypically identified as $V$. cholerae, five of which from water samples and four from sediment samples. There was no resistance to

Table 2

Composition and concentrations used in the reactions of the molecular study of $V$. cholerae strains isolated from water and sediments collected in four estuaries in Ceará, Brazil, between January and April 2009

\begin{tabular}{|c|c|c|c|c|c|}
\hline \multirow{3}{*}{ Reagents of the reaction* } & \multirow{3}{*}{$\begin{array}{c}\text { PCR } \\
\text { Species-specific gene } \\
\text { omp } W\end{array}$} & \multicolumn{4}{|c|}{ Multiplex PCR } \\
\hline & & \multicolumn{4}{|c|}{ Virulence genes } \\
\hline & & $\operatorname{ctx} A B$ & $t c p$ & $r f b O 1$ & $z o t$ \\
\hline Buffer 10X & $20 \mathrm{mM}$ Tris $\mathrm{pH} 8.4,50 \mathrm{mM} \mathrm{KCl}$ & \multicolumn{4}{|c|}{$20 \mathrm{mM}$ Tris $\mathrm{pH} 8.4,50 \mathrm{mM} \mathrm{KCl}$} \\
\hline dNTP's (2.5 mM) & $0.25 \mu \mathrm{M}$ & \multicolumn{4}{|c|}{$0.25 \mu \mathrm{M}$} \\
\hline Primer $F(10 \mu \mathrm{M})$ & $0.4 \mu \mathrm{M}$ & $0.4 \mu \mathrm{M}$ & $0.4 \mu \mathrm{M}$ & $0.4 \mu \mathrm{M}$ & $0.4 \mu \mathrm{M}$ \\
\hline $\operatorname{Primer} R(10 \mu \mathrm{M})$ & $0.4 \mu \mathrm{M}$ & $0.4 \mu \mathrm{M}$ & $0.4 \mu \mathrm{M}$ & $0.4 \mu \mathrm{M}$ & $0.4 \mu \mathrm{M}$ \\
\hline $\operatorname{MgCl} 2(50 \mathrm{mM})$ & $1.5 \mathrm{mM}$ & \multicolumn{4}{|c|}{$1.5 \mathrm{mM}$} \\
\hline Taq polymerase (500 U) & $4 \mathrm{U}$ & \multicolumn{4}{|c|}{$4 \mathrm{U}$} \\
\hline Sample & $20-35 \mathrm{ng}^{* *}$ & \multicolumn{4}{|c|}{$20-35 \mathrm{ng}^{* *}$} \\
\hline Final reaction volume & $25 \mu \mathrm{L}$ & \multicolumn{4}{|c|}{$25 \mu \mathrm{L}$} \\
\hline
\end{tabular}

$*$ = water q.s. was added to each reaction; ** = sample concentration varied from 20 to $25 \mathrm{ng}$. 


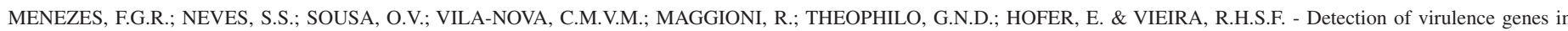
environmental strains of Vibrio cholerae from estuaries in Northeastern Brazil. Rev. Inst. Med. Trop. Sao Paulo, 56(5): 427-32, 2014.

the antimicrobial drugs tested in the nine Vibrio cholera strains found.

On PCR, only five percent $(55 \%)$ of the strains phenotypically identified were confirmed to be $V$. cholerae (Fig. 2). Phenotypic identification of Vibrio is often ambiguous due to intra-species biochemical variation ${ }^{16}$, whereas genotypic identification yields a $100 \%$ match for $V$. cholerae using an omp $W$-specific primer $^{31}$.

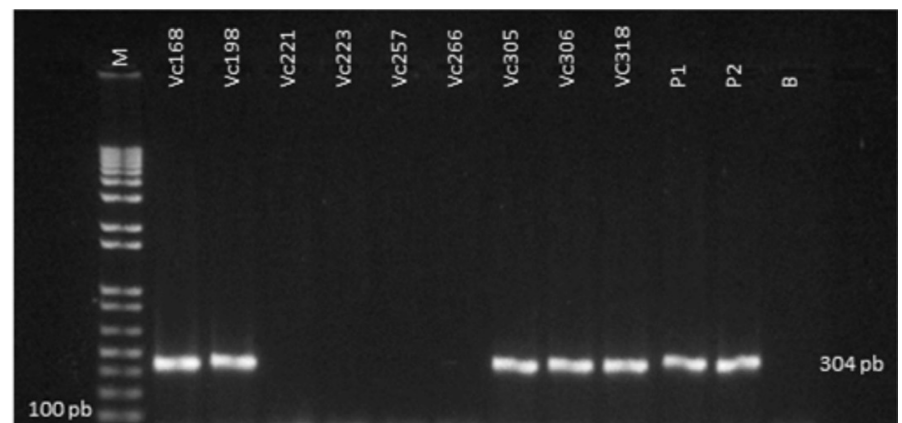

$\mathrm{P} 1=$ standard strain $V$. cholerae $\mathrm{O} 1$ classical 569B, $\mathrm{P} 2=$ standard strain $V$. cholerae non-O1 IOC $15.177, * \mathrm{M}=$ marker, $* * \mathrm{~B}=$ negative control (white).

Fig. 2 - Electrophoretic profile of nine strains identified genotypically as Vibrio cholerae using primers for the species-specific gene $\operatorname{OmpW}(304 \mathrm{pb})$ on PCR.

According to GOEL et al. ${ }^{10,12}$, OmpW acts as an internal control for $V$. cholerae, confirming the biochemical identification of suspected strains. This was recently demonstrated by JAIN et al. ${ }^{17}$ and by IZUMIYA et al. ${ }^{16}$ in studies based on clinical and environmental samples.

In the present study, the greatest number of V. cholerae strains (40\%) came from the Pirangi estuary, followed by Jaguaribe, Choró and Pacoti ( $20 \%$ each). The relatively small number of $V$. cholerae isolated $(n=5)$ matches the findings of SOUSA et al. ${ }^{33}$, who identified only eight strains of $V$. cholerae among 80 vibrio strains isolated from water and sediment samples collected in the same estuaries.

Figure 3 shows the electrophoretic profile of strains identified as Vibrio cholerae using primers for the virulence genes $\operatorname{ctx} A B(536 \mathrm{pb})$, tcp (805 pb), rfbO1 (638 pb) and zot (947 pb) on multiplex PCR. None of the isolates tested positive for these genes.

The absence on PCR of virulence genes in these environmental samples is supported by the findings of GONÇALVES et al. ${ }^{13}$ : none of their 31 strains of $V$. cholerae isolated from zooplankton, from Baía de São Marcos (São Luis, Maranhão, Brazil), was positive for ctxA, zot or ace.

In an analysis of water collected by LEAL et $a l .{ }^{20}$ from four rivers in Pernambuco (northeastern Brazil), strains of non-O1 and non-O139 $V$. cholerae tested negative for $c t x A$, zot and ace, and only one strain was positive for $t c p A$. In contrast, THEOPHILO et al. ${ }^{34}$ assessed the distribution of virulence markers in Brazilian clinical and environmental strains of non-O1 and non-O139 V. cholerae isolated between 1991 and 2000 and found one of two environmental samples to be positive for $c t x$, while zot, ace and $t c p$ were detected in clinical and environmental samples.

Nevertheless, according to SINGH et al..$^{32}$, environmental strains of $V$. cholerae do not carry the toxin TCP, which is responsible for one of

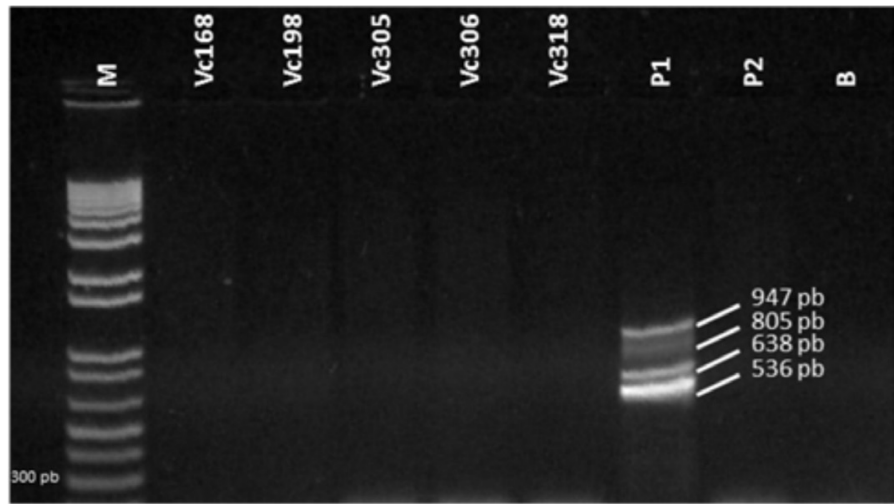

$\mathrm{P} 1$ = standard strain $V$. cholerae $\mathrm{O} 1$ classical 569B, $\mathrm{P} 2=$ standard strain $V$. cholerae non-O1 IOC $15.177, * \mathrm{M}=$ marker, $* * \mathrm{~B}=$ negative control (white).

Fig. 3 - Electrophoretic profile of strains identified as Vibrio cholerae $(\mathrm{Vc})$ using primers for the virulence genes $c t x A B(536 \mathrm{pb}), t c p(805 \mathrm{pb}), r f b O 1(638 \mathrm{pb})$ and $z o t(947 \mathrm{pb})$ on multiplex PCR.

the factors of pathogenicity in toxigenic strains belonging to serogroups $\mathrm{O} 1$ and $\mathrm{O} 139$. REEN \& BOYD ${ }^{28}$ have shown the predominant association between $c t x$ and $t c p$ genes and epidemic isolates of $V$. cholerae $\mathrm{O} 1$ and O139 serogroups.

The absence of virulence genes in environmental strains of $V$. cholerae is explained by DRYSELIUS et al. ${ }^{5}$, HEIDELBERG et al. ${ }^{14}$ and RASMUSSEN et al. ${ }^{27}$. According to these authors, all vibrios possess two chromosomes; in the case of $V$. cholerae, a large chromosome of $2.96 \mathrm{Mb}$ and a small chromosome of $1.07 \mathrm{Mb}$. SCHOONILK \& YILDIZ ${ }^{30}$ have shown that the large chromosome contains most of the genes required for growth and pathogenicity, while the small chromosome encodes a number of essential metabolic components and regulatory pathways. The duplicity of genetic elements can generate false results in DNA extraction-based gene detection studies. Thus, knowledge of the chromosomal location of target genes can help minimize false-negative results by optimizing the extraction and amplification protocols. However, according to NORIEGA-OROZCO et al $^{25}$, genotype studies have shown that $V$. cholerae, $V$. vulnificus and $V$. alginolyticus do not express virulence factors in natural environments.

The strains of non-O1 and non-O139 V. cholerae isolated from the water and sediments collected in four different estuaries for this study presented no virulence markers. However, there is evidence that, even in the absence of these virulence genes, non-O1 and non-O139 V. cholerae can cause diarrhea similar to cholera ${ }^{18}$, but do not generate epidemics. Many cases of diarrhoeal diseases related to non-O1 and non-O139 $V$. cholerae were reported ${ }^{2,7,21,26}$. In addition, environmental strains of $V$. cholerae may cause outbreaks in the future ${ }^{1,29}$, possibly triggered by environmental changes, or by lateral or horizontal transference of virulence genes mediated by phages, pathogenicity is lets and/or other mobile genetic elements encoding cholera toxin ${ }^{20,34}$, as previously reported for marine populations of $V$. cholerae and $V$. parahaemolyticus ${ }^{22}$.

\section{CONCLUSION}

The dichotomous key of NOGUEROLA \& $\mathrm{BLANCH}^{24}$ was efficient at differentiating environmental strains of $V$. cholerae isolated from 
MENEZES, F.G.R.; NEVES, S.S.; SOUSA, O.V.; VILA-NOVA, C.M.V.M.; MAGGIONI, R.; THEOPHILO, G.N.D.; HOFER, E. \& VIEIRA, R.H.S.F. - Detection of virulence genes in environmental strains of Vibrio cholerae from estuaries in Northeastern Brazil. Rev. Inst. Med. Trop. Sao Paulo, 56(5): 427-32, 2014.

four estuaries, confirming the importance of aquatic ecosystems in the dissemination, evolution and, in some cases, transmission of this pathogen to humans.

Although these strains possessed no virulence genes capable of causing cholera, environmental strains can evolve into epidemic lineages through contact with toxigenic strains.

\section{RESUMO}

\section{Detecção de genes de virulência em estirpes de Vibrio cholerae isolados de estuários no Nordeste do Brasil}

O objetivo deste estudo foi detectar a presença potencial virulência de Vibrio cholerae isolado de estuários do Nordeste do Brasil. Amostras de água e sedimento foram coletadas e inoculadas sobre meio seletivo para víbrios (TCBS) e colônias com características morfológicas de $V$. cholerae foram isoladas. A identificação fenotípica seguiu chave dicotômica baseada em caraterísticas bioquímicas. Foram empregadas as técnicas de amplificação da polimerase em cadeia (PCR) utilizando o gene omp $W$ e a de multiplex PCR para detecção de genes de virulência (ctx, $t c p$, zot e $r f b O 1$ ). Os resultados da identificação das diferentes abordagens foram comparados. Nove cepas de $V$. cholerae foram identificadas fenotipicamente e cinco confirmadas através da detecção do gene $o m p W$. A chave dicotômica utilizada foi eficiente para a confirmação da espécie. Os quatro estuários analisados apresentaram estirpes de $V$. cholerae, e nenhuma das cepas isoladas apresentaram genes de virulência.

\section{ACKNOWLEDGMENTS}

The authors would like to thank the government research promotion agencies FUNCAP and CAPES for financial support.

\section{REFERENCES}

1. Cariri FAMO, Costa APR, Melo CC, Theophilo GND, Hofer E, Melo Neto OP, et al Characterization of potentially virulent non-O1/non-O139 Vibrio cholerae strains isolated from human patients. Clin Microbiol Infect. 2010;16:62-7.

2. Chatterjee S, Ghosh K, Raychoudhuri A, Chowdhury G, Bhattacharya MK, Mukhopadhyay AK, et al. Incidence, virulence factors, and clonality among clinical strains of non-O1, non-O139 Vibrio cholerae isolates from hospitalized diarrheal patients in Kolkata, India. J Clin Microbiol. 2009;47:1087-95.

3. Clinical and Laboratory Standards Institute. Performance standards for antimicrobial susceptibility testing; twenty-third informational supplement. Wayne: CLSI; 2013. (Document M100-S23).

4. Colaço W, Silva Filho SV, Rodrigues DP, Hofer E. Vibrio cholerae O1 em amostras de ambientes aquáticos e de alimentos analisados no Estado de Pernambuco, Brasil. Cad Saúde Pública. 1998;14:465-71.

5. Dryselius R, Kurokawa K, Iida T. Vibrionaceae, a versatile bacterial family with evolutionarily conserved variability. Res Microbiol. 2007;158:479-86.

6. DSMZ. Leibniz-Institu Deutsche Sammlung von Mikroorganismen und Zellkulturen GmbH. Bacterial diversity. [cited 2012 Jan. 24]. Available from: http://www.dsmz. de/bacterial-diversity.html

7. Dutta D, Chowdhury G, Pazhani GP, Guin S, Dutta S, Ghosh S, et al. Vibrio cholerae non-O1, non-O139 serogroups and cholera-like diarrhea, Kolkata, India. Emerg Infect Dis. 2013;19:464-7.
8. Filizola LRS, Figueirôa ACTA, Araújo MCMD, Cavalcanti VO, Lima CM, Hofer E. Significância de anticorpos vibriocidas circulantes em área pós-epidêmica de diarréia, São Bento do Uma, Estado de Pernambuco. Rev Soc Bras Med Trop. 2007;40:686-9.

9. Fraga SG, Pichel M, Costagliola M, Cecilia M, Jurquiza V, Peressutti S, et al. Environment and virulence factors of Vibrio cholerae strains isolated in Argentina. J Appl Microbiol. 2007; $103: 2448-56$.

10. Goel AK, Jain M, Kumar P, Jiang SC. Molecular characterization of Vibrio cholerae outbreak strains with altered El Tor biotype from southern India. World J Microbiol Biotechnol. 2010;26:281-7.

11. Goel AK, Jiang SC. Genetic determinants of virulence, antibiogram and altered biotype among the Vibrio cholerae $\mathrm{O} 1$ isolates from different cholera outbreaks in India. Infect Gent Evol. 2010;10:815-9.

12. Goel AK, Ponmariappan S, Kambol DV, Singh L. Single multiplex polymerase chain reaction for environmental surveillance of toxigenic-pathogenic $\mathrm{O} 1$ and non-O1 Vibrio cholerae. Folia Microbiol. 2007;52:81-5.

13. Gonçalves EGR, Leal NC, Hofer E. Estudo molecular de Vibrio cholerae não-O1 isolado de zooplâncton da Baía de São Marcos/São Luis - MA, Brasil. Rev Soc Bras Med Trop. 2004;37:324-8.

14. Heidelberg JFJA, Eisen WC, Nelson WC, Clayton RA, Gwinn ML, Dodson RJ, et al. DNA sequence of both chromosomes of the cholera pathogen Vibrio cholerae. Nature. 2000;406:477-83.

15. Hofer E, Reis EMF, Quintaes BR, Rodrigues DP, Feitosa IS, Angelo MRF, et al. Vibrio cholerae resistant to 2,4-diamino-6, 7-diisopropylpteridine $(\mathrm{O} / 129)$ isolated from patients with enteritis in Ceará, Brazil. J Health Popul Nutr. 2001;19:39-42.

16. Izumiya H, Matsumoto K, Yahiro S, Lee J, Morita M, Yamamoto S, et al. Multiplex PCR assay for identification of three major pathogenic Vibrio spp., Vibrio cholerae, Vibrio parahaemolyticus, and Vibrio vulnificus. Mol Cell Probes. 2011;25:174-6.

17. Jain M, Goel AK, Bhattacharya P, Ghatole M, Kamboj DV. Multidrug resistant Vibrio cholerae $\mathrm{O} 1 \mathrm{El}$ Tor carrying classical ctxB allele involved in a cholera outbreak in South Western India. Acta Trop. 2011;117:152-6.

18. Jagadeeshan S, Kumar P, Abraham WP, Thomas S. Multiresistant Vibrio cholerae non-O1/ non-O139 from waters in South India: resistance patterns and virulence-associated gene profiles. J Basic Microbiol. 2009;49:538-44.

19. Kaysner CA, Depaola A. Vibrio. In: Bacteriological analytical manual on line. Rockville: U.S. Food and Drug Administration; 2004. Chapter 9. [cited 2012 Jan 13]. Available from: < http://www.cfsan.fda.gov/ ebam/bam-9.html >.

20. Leal NC, Figueiroa ACTA, Cavalcanti VO, Silva SC, Leal-Balbino TC, Almeida AMP, et al. Characterization of Vibrio cholerae isolated from the aquatic basins of the State of Pernambuco, Brazil. Trans R Soc Trop Med Hyg. 2008;102:272-6.

21. Lukinmaa S, Mattila K, Lehtinen V, Hakkinen M, Koskela M, Siitonen A. Territorial waters of the Baltic Sea as a source of infections caused by Vibrio cholerae non-O1, non-O139: report of 3 hospitalized cases. Diagn Microbiol Infect Dis. 2006;54:1-6.

22. Masini L, De Grandis G, Principi F, Mengarelli C, Ottaviani D. Research and characterization of pathogenic vibrios from bathing water along the Conero Riviera (Central Italy). Water Res. 2007;41:4031-40.

23. Nandi B, Nandy R, Mukhopadhyay S, Nair GB, Shimada T, Ghose AC. Rapid method for species-specific identification of Vibrio cholerae using primers targeted to the gene of outer membrane protein OmpW. J Clin Microbiol. 2000;38:4145-51.

24. Noguerola I, Blanch AR. Identification of Vibrio spp. with a set of dichotomous keys. J Appl Microbiol. 2008;105:175-85. 
MENEZES, F.G.R.; NEVES, S.S.; SOUSA, O.V.; VILA-NOVA, C.M.V.M.; MAGGIONI, R.; THEOPHILO, G.N.D.; HOFER, E. \& VIEIRA, R.H.S.F. - Detection of virulence genes in environmental strains of Vibrio cholerae from estuaries in Northeastern Brazil. Rev. Inst. Med. Trop. Sao Paulo, 56(5): 427-32, 2014.

25. Noriega-Orozco L, Acedo-Félix E, Higuera-Ciapara I, Jiménez-Flores R, Cano T. Pathogenic and non pathogenic Vibrio species in aquaculture shrimp ponds. Rev Latinoam Microbiol. 2007;49:60-7.

26. Ottaviani D, Leoni F, Rocchegiani E, Santarelli S, Masini L, Trani VD, et al. Prevalence and virulence properties of non-O1 non-O139 Vibrio cholerae strains from seafood and clinical samples collected in Italy. Int J Food Microbiol. 2009;132:47-53.

27. Rasmussen T, Jensen RB, Skovgaard O. The two chromosomes of Vibrio cholerae are initiated at different time points in the cell cycle. EMBO J. 2007;26:3124-31.

28. Reen FJ, Boyd EF. Molecular typing of epidemic and nonepidemic Vibrio cholerae isolates and differentiation of V. cholerae and V.mimicus isolates by PCR-single-strand conformation polymorphism analysis. J Appl Microbiol. 2005;98:544-55.

29. Rivera ING, Chun J, Huq A, Sack RB, Colwell RR. Genotypes associated with virulence in environmetal isolates of Vibrio cholerae. Appl Environ Microbiol. 2001;67:2421-9.

30. Schoolnik GK, Yildiz FH. The complete genome sequence of Vibrio cholerae: a tale of two chromosomes and of two lifestyles. Genome Biol. 2000;1:REVIEWS 1016

31. Sharma A, Chaturvedi AN. Prevalence of virulence genes ( $c t x A, \operatorname{stn}, O m p W$ and $t c p A)$ among non-O1 Vibrio cholerae isolated from fresh water environment. Int J Hyg Environ Health. 2006;209:521-6.
32. Singh DV, Matte MH, Matte GR, Jiang S, Sabeena F, Shukla BN, et al. Molecular analysis of Vibrio cholerae O1, O139, non-O1, and non-O139 strains: clonal relationships between clinical and environmental isolates. Appl Environ Microbiol. 2001;67:91021.

33. Sousa OV, Macrae A, Menezes FGR, Gomes NCM, Vieira RHSF, Mendonça-Hagler LCS. The impact of shrimp farming effluent on bacterial communities in mangrove waters, Ceará, Brazil. Mar Pollut Bull. 2006;52:1725-34

34. Theophilo GND, Rodrigues DP, Leal NC, Hofer E. Distribution of virulence marker in clinical and environmental Vibrio cholerae non-O1/non-O139 strains isolated in Brazil from 1991 to 2000. Rev Inst Med Trop Sao Paulo. 2006;48:65-70.

35. Vezzulli L, Pruzzo C, Huq A, Colwell RR. Environmental reservoirs of Vibrio cholerae and their role in cholera. Environ Microbiol Rep. 2012;2:27-33.

36. Xu J, Zhang J, Lu X, Liang W, Zhang L, Kan B. O antigen is the receptor of Vibrio cholerae serogroup O1 El Tor typing phage VP4. J Bacteriol. 2013;195:798-806.

Received: 8 March 2013

Accepted: 25 February 2014 